\title{
Kajian Karakteristik Beton Memadat Sendiri yang Menggunakan Serat Ijuk
}

\author{
IIS NURJAMILAH, ABINHOT SIHOTANG
}

\author{
Jurusan Teknik Sipil, Institut Teknologi Nasional, Bandung \\ Email: iisnurjamilah9@gmail.com
}

\begin{abstract}
ABSTRAK
Kajian karakteristik beton memadat sendiri yang menggunakan serat ijuk merupakan sebuah kajian yang dilakukan untuk mengetahui pengaruh penambahan serat ijuk terhadap karakteristik beton memadat sendiri (SCC). Beton memadat sendiri yang menggunakan serat ijuk (PFSCC) didesain memiliki campuran yang encer, bermutu tinggi $\left(f_{c}^{\prime}=40 \mathrm{MPa}\right)$ dan memiliki persentase kekuatan lentur yang lebih baik. PFSCC didapatkan dari hasil pencampuran antara semen sebanyak $85 \%$, fly ash $15 \%$, superplastizicer 1,5\%, serat ijuk 0\%, 0,5\%; $1 \% ; 1,5 \% ; 2 \%$ dan 3\% dari berat binder (semen + fly ash), kadar air $190 \mathrm{~kg} / \mathrm{m}^{3}$, agregat $\mathrm{kasar} 552,47 \mathrm{~kg} / \mathrm{m}^{3}$ dan pasir $1.063 \mathrm{~kg} / \mathrm{m}^{3}$. Semakin banyak persentase penambahan serat ijuk ke dalam campuran berdampak terhadap menurunnya workability beton segar. Penambahan serat ijuk yang paling baik adalah sebanyak $1 \%$, penambahan tersebut dapat meningkatkan kekuatan tekan beton sebesar $13 \%$ dan lentur sebesar $1,8 \%$.
\end{abstract}

Kata kunci: beton memadat sendiri (SCC), beton berserat, beton memadat sendiri yang menggunakan serat ijuk (PFSCC), serat ijuk

\begin{abstract}
The study of characteristics self compacting concrete using palm fibers is a study conducted to determine the effect of adding palm fibers to characteristics of self compacting concrete (SCC). palm fibers self compacting concrete (PFSCC) is designed to have a dilute mixture, high strength $\left(f c^{\prime}=40 \mathrm{MPa}\right)$, and have better precentage flexural strength. PFSCC was obtained from mixing of $85 \%$ cement, $15 \%$ fly ash, $1.5 \%$ superplastizicer, $0 \%, 0.5 \%, 1 \%, 1.5 \%, 2 \%$ and $3 \%$ palm fibers from the weight of binder (cement + fly ash), water content $190 \mathrm{~kg} / \mathrm{m}^{3}$, coarse aggregate $552.47 \mathrm{~kg} / \mathrm{m}^{3}$ and sand $1,063 \mathrm{~kg} / \mathrm{m}^{3}$. The more persentage palm fibers content added to the mixture makes workability of fresh concrete decreases. The best addition of palm fiber is $1 \%$, this addition can increases the compressive strength $13 \%$ and flexural strength $1.8 \%$.
\end{abstract}

Keywords: self compacting concrete (SCC), fiber concrete, Palm fiber self compacting concrete (PFSCC), palm fiber 


\section{PENDAHULUAN}

Beton merupakan bahan bangunan yang paling banyak digunakan, hal ini membuatnya dituntut untuk memiliki campuran beton dengan workability yang lebih baik. Beton memadat sendiri (self compacting concrete (SCC)) merupakan jenis beton yang didesain memiliki campuran yang encer. SCC memiliki kelebihan seperti: mampu memadat sendiri, lebih homogen, mudah mengisi celah-celah yang sempit, permukaan yang dihasilkan lebih halus, ramah lingkungan karena tidak dilakukan proses pemadatan, cepat dalam pengerjaan, dan lebih awet. Selain kelebihan yang dimilikinya, beton SCC memiliki kekurangan yang sama seperti beton konvensional yaitu memiliki kelemahan terhadap tarik. Beton berserat merupan solusi untuk memperbaiki kekurangan yang dimiliki SCC. Salah satu serat alam yang baik dan mudah didapatkan adalah serat ijuk. Beberapa hasil penelitian mengatakan penambahan serat ijuk ke dalam campuran beton dapat meningkatkan kekuatan tarik pada beton. Melalui penelitian ini diharapkan dapat diperoleh jenis beton berserat yang mampu memadat dengan sendirinya, berkekuatan tinggi dan memiliki kemampuan untuk menahan tarik lebih baik.

Permasalahan yang akan dibahas selama penelitian adalah pengaruh penambahan serat terhadap karakteristik beton segar dan keras SCC, dengan tujuan untuk mengkaji karakteristik beton Palm Fiber Self-compacting Concrete (PFSCC).

Lingkup penelitian yang dilakukan selama proses penelitian adalah sebagai berikut:

1. Kuat tekan rencana $f_{c}^{\prime}=40 \mathrm{MPa}$.

2. Panjang serat ijuk $10-15 \mathrm{~mm}$.

3. Diameter serat ijuk $0,2-0,6 \mathrm{~mm}$.

4. Rasio $l / d=50-15$.

5. Kadar fly ash $15 \%$ terhadap berat binder (semen+fly ash).

6. Kadar ijuk $0 \%, 0,5 \%, 1 \%, 1,5 \%, 2 \%$ dan 3\% terhadap berat binder.

7. Umur pengujian 14 hari dan 28 hari.

8. Kadar superplastizicer 1,5\% terhadap berat binder.

9. Pengujian yang akan dilakukan kuat tekan dan lentur.

10. Perencanaan mix design menggunakan SNI yang kemudian hasilnya dimodifikasi menggunakan metode Dreux untuk mendekati prinsip perancangan Okamura.

11. Tempat penelitian dilakukan di Laboratorium Struktur dan Bahan Itenas, Laboratorium Struktur ITB, dan Laboratorium Struktur PUSJATAN.

\section{TINJAUAN PUSTAKA}

\subsection{Beton SCC}

Komposisi material pencampur SCC dapat dilihat pada Gambar 1 berikut.
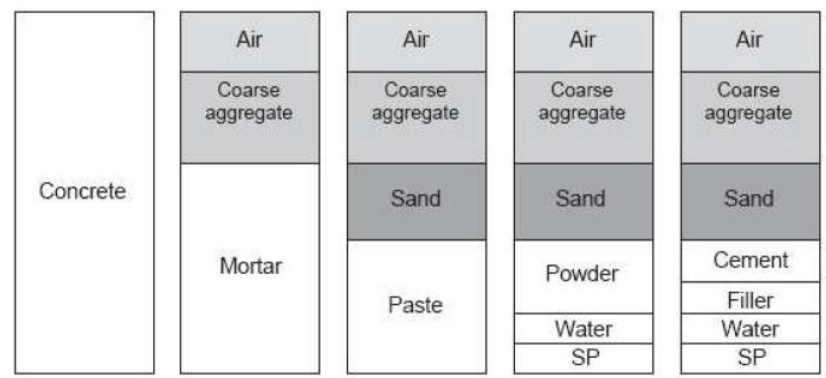

Gambar 1. Komposisi material penyusun SCC (Sumber: Herbudiman, B. dan Siregar, S. E., 2013) 
SCC ditemukan oleh Hajime Okamura pada tahun 1986 di Universitas Kochi Jepang. SCC tercipta atas permasalahan kesulitan pengecoran beton konvensional pada keadaan celah yang sempit. Okamura memberikan metode yang dapat digunakan untuk mendapatkan campuran SCC seperti yang terlihat pada Gambar 2 berikut.

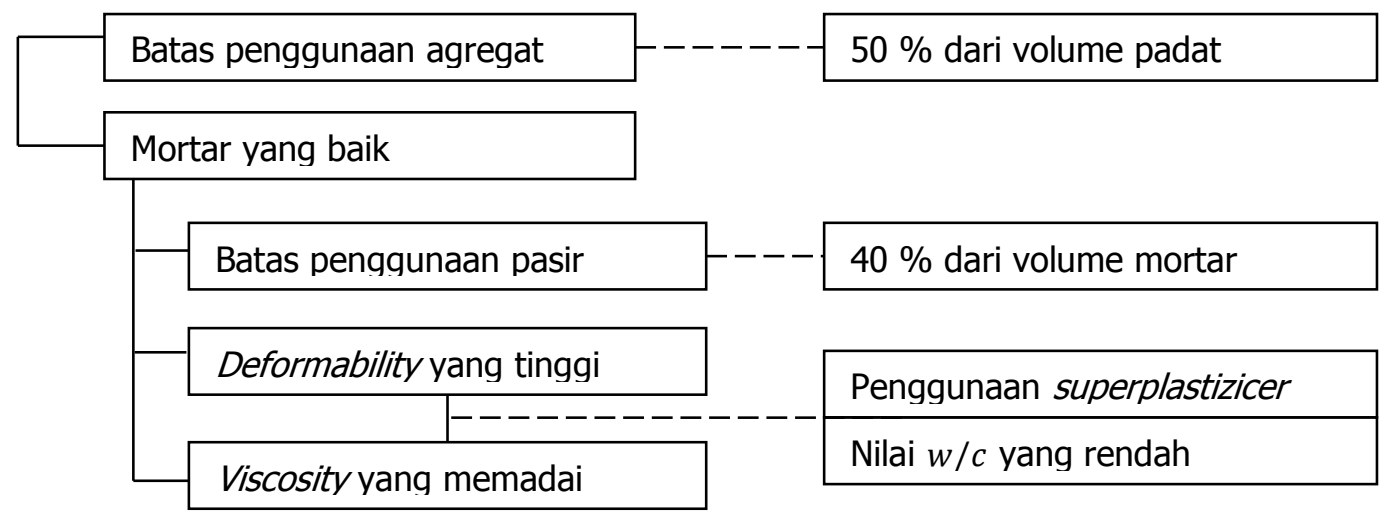

Gambar 2. Metode untuk Mendapatkan Campuran SCC (Sumber: Okamura, H. dan Ouichi, M., 2003)

Beton segar dikatakan SCC jika campuran memenuhi tiga syarat yaitu: mampu mengalir, melewati celah, dan mencegah terjadinya segregasi. Ketiga syarat tersebut dapat diketahui nilainya dengan melakukan pengujian yang dapat dilihat pada Tabel $\mathbf{1}$ dan syarat nilai yang harus dicapai beton SCC dapat dilihat pada Tabel 2.

Tabel 1. Pengukuran Nilai Pengujian Beton Segar SCC

\begin{tabular}{|c|c|c|}
\hline Caracteristic & Test method & Measured value \\
\hline \multirow{2}{*}{ Flowability/filling ability } & Slump-flow & total spread \\
\hline & Kajima box & visual filling \\
\hline \multirow{4}{*}{ Viscosity/ flowability } & $T_{500}$ & flow time \\
\hline & V-funnel & flow time \\
\hline & O-funnel & flow time \\
\hline & Orimet & flow time \\
\hline \multirow{4}{*}{ Passing ability } & $L-b o x$ & passing ratio \\
\hline & $U-b o x$ & height difference \\
\hline & J-ring & step height, total flow \\
\hline & Kajima box & visual passing ability \\
\hline \multirow{3}{*}{ Segregation resistance } & penetration & depth \\
\hline & sieve segregation & percent laitance \\
\hline & settlement column & segregation ratio \\
\hline
\end{tabular}

(Sumber: EFNARC, 2005)

Tabel 2. Syarat Nilai Pengujian Beton Segar SCC

\begin{tabular}{clcccc}
\hline \multirow{2}{*}{ No. } & \multicolumn{1}{c}{ Jenis Pengujian } & \multicolumn{2}{c}{ Standar Nilai } & \multirow{2}{*}{ Satuan } & \multirow{2}{*}{ Acuan } \\
\cline { 3 - 5 } & Min & Maks & & \\
\hline \multirow{2}{*}{1} & $\begin{array}{l}\text { Slump Flow kurang dari atau } \\
\text { sama dengan } 550 \mathrm{~mm}\end{array}$ & 510 & 590 & {$[\mathrm{~mm}]$} & (SNI 4433:2016) \\
\hline 2 & Slump Flow lebih dari $550 \mathrm{~mm}$ & 485 & 615 & {$[\mathrm{~mm}]$} & (SNI 4433:2016) \\
\hline 3 & $T_{500}$ & \multicolumn{2}{c}{$\leq 2$} & {$[$ detik] } & (EFNARC, 2005) \\
\hline 4 & $T_{500}$ & \multicolumn{2}{c}{$>2$} & [detik] & (EFNARC, 2005) \\
\hline 5 & V-Funne/ jika $T_{500} \leq 2$ detik & \multicolumn{2}{c}{$\geq 8$} & [detik] & (EFNARC, 2005) \\
\hline 6 & V-Funne/ jika $T_{500}>2$ detik & 9 & 25 & [detik] & (EFNARC, 2005) \\
\hline 7 & L-Box & $\geq 0,8$ & & -- & (EFNARC, 2005) \\
\hline
\end{tabular}




\subsection{Beton Berserat}

Beton berserat didesain untuk memiliki kekuatan tarik yang lebih baik. Beberapa faktor yang harus diperhatikan dalam pembuatan beton berserat yaitu penggunaan rasio $l / d$ dan volume fraksi. Semakin kecilnya nilai rasio $l / d$ dan volume fraksi [\%] maka akan membuat campuran lebih mudah untuk dikerjakan. Gambar $\mathbf{3}$ dan Gambar 4 memperlihatkan grafik pengaruh rasio $l / d$ dan volume fraksi [\%] terhadap workability.

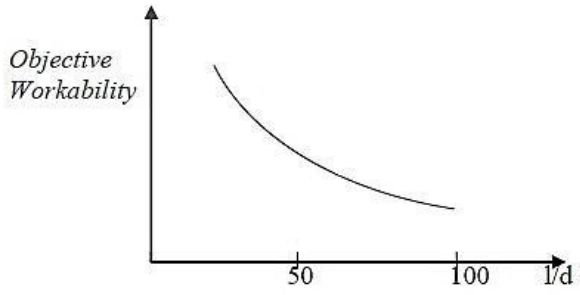

Gambar 3. Grafik pengaruh aspek rasio serat terhadap workability

(Sumber: Simarmata, A. C. N., 2015)

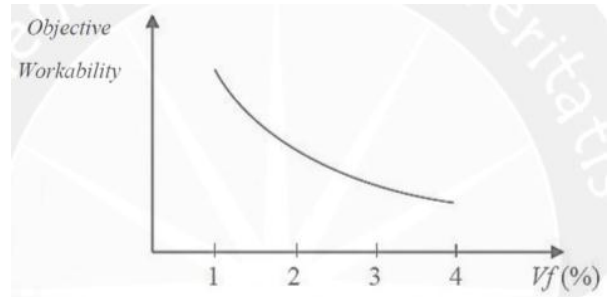

Gambar 4. Grafik pengaruh volume fraksi serat terhadap workability

(Sumber: Simarmata, A. C. N., 2015)

Kuat tarik yang dimiliki serat ijuk cukup tinggi dan semakin kecil ukuran diameter serat maka kekuatan yang dimilikinya semakin besar (Munandar, I., et al., 2013). Penambahan serat ijuk ke dalam campuran beton dapat memberikan kekuatan tarik yang lebih baik (Darul, et al., 2013). Kesulitan yang didapatkan dari penambahan serat kedalam campuran beton segar adalah kemungkinan besar akan terjadi penyebaran serat ijuk yang tidak merata, dan terjadi penggumpalan. Terlalu banyaknya penggunaan volume fraksi [\%] pada campuran dapat mengakibatkan kesulitan pengerjaan dan mengakibatkan penurunan terhadap kekuatan beton (Rochmah, N., 2017).

\subsection{Material Penyusun Palm Fiber Self Compacting Concrete (PFSCC)}

\subsubsection{Semen}

Semen adalah bahan perekat hidrolis-anorganik yang berbentuk powder halus yang memiliki sifat mengikat (adhesif \& kohesif). Tabel $\mathbf{3}$ memberikan informasi mengenai jenis-jenis semen dan kandungan senyawa kimia yang terdapat di dalamnya.

Tabel 3. Syarat Nilai Pengujian Beton Segar SCC

\begin{tabular}{clccccc}
\hline \multirow{2}{*}{$\begin{array}{c}\text { Jenis } \\
\text { Semen }\end{array}$} & \multirow{2}{*}{ Sifat Pemakaian } & \multicolumn{4}{c}{ Kadar Senyawa [\%] } & Panas Hidrasi \\
\cline { 2 - 6 } & Normal & $\mathbf{C S}_{\mathbf{3}}$ & $\mathbf{C}_{\mathbf{2}} \mathbf{S}$ & $\mathbf{C}_{\mathbf{3}} \mathbf{A}$ & $\mathbf{C}_{\mathbf{4}} \mathbf{A F}$ & $\mathbf{7}$ Hari $[\boldsymbol{J} / \boldsymbol{g}]$ \\
\hline \multirow{2}{*}{ II \& III } & Modifikasi & 50 & 24 & 11 & 8 & 330 \\
\cline { 2 - 7 } & Kekuatan Awal & 42 & 33 & 5 & 13 & 250 \\
\hline IV & Tinggi Panas Hidrasi & 60 & 13 & 9 & 8 & 500 \\
\hline V & Rendah Tahan Sulfat & 26 & 50 & 5 & 12 & 210 \\
\hline
\end{tabular}

(Sumber: ASTM C 150-07, 2007)

Penjelasan mengenai jenis-jenis semen adalah sebagai berikut (SNI 15-2049-2004):

1. Jenis I, yaitu semen portland untuk kontruksi umum yang penggunaannya tidak memerlukan persyaratan-persyaratan khusus

2. Jenis II, yaitu semen portland untuk kontruksi yang memerlukan ketahanan terhadap sulfat dan panas hidrasi sedang.

3. Jenis III, yaitu semen portland untuk kontruksi yang menuntut persyaratan kekuatan awal yang tinggi.

4. Jenis IV, yaitu semen portland untuk kontruksi yang menuntut persyaratan panas hidrasi yang rendah. 
5. Jenis $\mathrm{V}$, yaitu semen portland untuk kontruksi yang menuntut persyaratan sangat tahan terhadap sulfat.

\subsubsection{Agregat Kasar}

Agregat kasar adalah kerikil sebagai hasil disintegrasi alami batuan dari batuan berupa batu pecah yang diperoleh dari industri pemecah batu dan mempunyai ukuran butir antara 4,75 mm (No. 4) sampai 40 mm (No. 1,5 inci) (SNI 1970:2008).

\subsubsection{Agregat Halus}

Agregat halus adalah pasir alam sebagai hasil disintegrasi alami batuan atau pasir yang dihasilkan oleh industri pemecah batu dan mempunyai ukuran butir terbesar 4,75 mm (No. 4) (SNI 1970:2008).

\subsubsection{Air}

Kualitas air yang dipakai dapat berpengaruh terhadap hasil kualitas beton, maka air yang digunakan harus memenuhi syarat bersih dan bebas dari bahan-bahan perusak seperti oli, garam, asam dan lain sebagainya.

\subsubsection{Superplastizicer}

Superplastizicer adalah bahan kimia tambahan pengurang air yang sangat efektif. Keuntungan penambahan superplastizicer ke dalam campuran adalah menambah kekuatan tekan (compressive strength), menambah kekuatan flexural, modulus elestisitas tinggi, permeabilitas yang rendah, meningkatkan durability, dan meningkatkan workability beton segar.

\subsubsection{Fly Ash}

Fly ash adalah limbah dari hasil pembakaran batubara pada tungku pembangkit listrik tenaga uap yang berbentuk halus, bundar, serata bersifat pozolanik (SNI 03-6863-2002). Spesifikasi jenis fly ash dan kandungan senyawa di dalamnya dijelaskan pada Tabel 4 berikut.

Tabel 4. Klasifikasi Fly Ash

\begin{tabular}{lccc}
\hline \multirow{2}{*}{ Kandungan } & \multicolumn{3}{c}{ Kelas Fly Ash } \\
\cline { 2 - 4 } & $\mathbf{N}$ & $\boldsymbol{F}$ & $\mathbf{C}$ \\
\hline $\mathrm{SiO}_{2}+\mathrm{Al}_{2} \mathrm{O}_{3}+\mathrm{Fe}_{2} \mathrm{O}_{3}$, min \% & 70 & 70 & 50 \\
\hline $\mathrm{SiO}_{3}$, maks \% & 4 & 5 & 5 \\
\hline Kadar air, maks \% & 3 & 3 & 3 \\
\hline Loss on ignition, maks \% & 10 & 6 & 6 \\
\hline
\end{tabular}

(Sumber: ASTM C618, 2017)

\subsubsection{Serat Ijuk}

Serat ijuk adalah serat alam, berwarna hitam, dan memiliki kekuatan tarik yang cukup tinggi. Serat ijuk memiliki diameter kurang lebih $0,2-0,6 \mathrm{~mm}$. Serat yang baik digunakan adalah serat ijuk yang bersih dan bebas dari kotoran hasil proses pembersihan dan penyisiran.

\subsection{Pengujian Sifat Mekanik Beton}

\subsubsection{Kuat Tekan $\left(f_{c}^{\prime}\right)$}

Kuat tekan adalah kemampuan beton untuk menerima gaya/beban yang diberikan persatuan luas. Perhitungan kuat tekan beton dapat dilihat pada Persamaan 1 (SNI 1974:2011).

keterangan:

$$
f_{c}^{\prime}=\frac{P}{A}
$$

$f_{c}^{\prime} \quad=$ kuat tekan [MPa], 
$P \quad=$ Beban tekan maksimum yang dapat ditahan $[\mathrm{N}]$,

$A \quad=$ Luas penampang benda uji $\left[\mathrm{mm}^{2}\right]$.

\subsubsection{Kuat Lentur $\left(f_{r}\right)$}

Kuat lentur adalah kemampuan balok beton yang diletakkan pada dua perletakkan untuk menahan gaya arah tegak lurus sumbu. Persamaan 2 berikut dapat digunakan untuk menghitung nilai kuat lentur (SNI 4431:2011).

$$
f_{r}=\frac{P L}{b h^{2}}
$$

Keterangan:

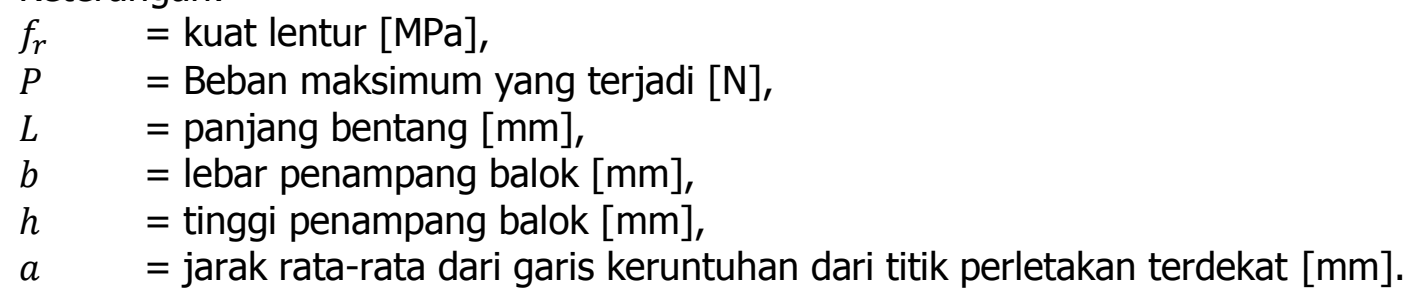

\section{METODOLOGI PENELITIAN}

Tahapan-tahapan penelitian kajian karakteristik beton memadat sendiri yang menggunakan serat ijuk adalah menentukan judul penelitian, mencari dasar-dasar teori dan hasil penelitian terdahulu yang berkaitan dengan topik penelitian, mempersiapkan alat dan bahan, melakukan pemeriksaan bahan sesuai SNI, perancangan komposisi campuran menggunakan metode SNI 2834-2000 yang kemudian dimodifikasi menggunakan metode Dreux, trial mix, pengujian beton segar, pembuatan benda uji, curing, pengujian beton keras, menganalisis dan membahas, menarik kesimpulan dan memberikan saran terhadap hasil penelitian.

\section{ANALISIS DAN PEMBAHASAN}

\subsection{Persiapan Bahan}

Bahan yang digunakan untuk pembuatan benda uji adalah air yang tidak berwarna, berbau dan tidak berasa yang sudah tersedia di Laboratorium Pusjatan, semen tipe 1 dengan merek Tiga Roda, Fly ash dari sisa pembakaran batu bara PLTU Cilegon-Suralaya, serat ijuk dari Malangbong-Garut dengan panjang 10-15 mm, batu pecah dari Gunung Lagadar dengan ukuran maksimum 20 mm, pasir Cimalaka lolos saringan No. 4 dan tertahan di saringan No. 200 dan superplastizicer dengan merek Sika-Viscocrete 3.115 N. Bahan yang digunakan untuk pembuatan benda uji PFSCC lebih banyak dibandingkan dengan beton normal, sehingga biaya yang dibutuhkan untuk pembuatan benda uji lebih mahal. Selain biaya yang cukup mahal proses pengadaan serat ijuk pada penelitian cukup lama karena untuk mendapatkan serat dengan panjang 10-15 mm seberat $1 \mathrm{~kg}$ didapatkan selama 6 jam oleh 6-7 orang per harinya.

\subsection{Hasil Pemeriksaan Bahan}

Pemeriksaan bahan dilakukan di Laboratorium Struktur dan Bahan Itenas, rekapitulasi hasil pemeriksaan agregat kasar dan halus di Laboratorium disajikan pada Tabel $\mathbf{5}$ berikut. 
Tabel 5. Hasil Pemeriksaan Bahan Agregat Kasar dan Agregat Halus

\begin{tabular}{|c|c|c|c|c|c|}
\hline \multirow{2}{*}{ No. } & \multirow{2}{*}{ Jenis Pengujian } & \multirow{2}{*}{$\begin{array}{c}\text { Hasil } \\
\text { Pengujian }\end{array}$} & \multicolumn{2}{|c|}{ Standar Nilai } & \multirow{2}{*}{ Acuan } \\
\hline & & & Min & Maks & \\
\hline $\mathbf{I}$ & Agregat Kasar & & & & \\
\hline 1 & Berat jenis semu $\left[\mathrm{gr} / \mathrm{cm}^{3}\right]$ & 2,734 & \multirow{3}{*}{2,400} & \multirow{3}{*}{2,900} & \multirow{3}{*}{ ASTM.C-127 } \\
\hline 2 & Berat jenis kondisi kering $\left[\mathrm{gr} / \mathrm{cm}^{3}\right]$ & 2,532 & & & \\
\hline 3 & Berat Jenis Kondisi SSD $\left[\mathrm{gr} / \mathrm{cm}^{3}\right]$ & 2,606 & & & \\
\hline 4 & Penyerapan $[\%]$ & 2,923 & - & 3,000 & PB-0202-76 \\
\hline 5 & Kadar Air [\%] & 2,987 & - & - & - \\
\hline 6 & Berat isi padat $\left[\mathrm{gr} / \mathrm{cm}^{3}\right]$ & 1,445 & \multirow{2}{*}{1,200} & \multirow{2}{*}{1,750} & \multirow{2}{*}{ ASTM.C-29 } \\
\hline 7 & Berat isi gembur $\left[\mathrm{gr} / \mathrm{cm}^{3}\right]$ & 1,293 & & & \\
\hline 8 & Modulus kehalusan [\%] & 6,922 & 6,000 & 8,000 & SNI-90 \\
\hline II & Agregat Halus & & & & \\
\hline 1 & Berat jenis semu $\left[\mathrm{gr} / \mathrm{cm}^{3}\right]$ & 2,761 & \multirow{3}{*}{2,300} & \multirow{3}{*}{2,900} & \multirow{3}{*}{ ASTM.C-127 } \\
\hline 2 & Berat jenis kondisi kering $\left[\mathrm{gr} / \mathrm{cm}^{3}\right]$ & 2,372 & & & \\
\hline 3 & Berat Jenis Kondisi SSD $\left[\mathrm{gr} / \mathrm{cm}^{3}\right]$ & 2,513 & & & \\
\hline 4 & Penyerapan [\%] & 5,940 & & 5,000 & PB-0202-76 \\
\hline 5 & Kadar Air [\%] & 4,593 & - & - & - \\
\hline 6 & Berat isi padat $\left[\mathrm{gr} / \mathrm{cm}^{3}\right]$ & 1,446 & \multirow{2}{*}{1,200} & \multirow{2}{*}{1,750} & \multirow{2}{*}{ ASTM.C-29 } \\
\hline 7 & Berat isi gembur $\left[\mathrm{gr} / \mathrm{cm}^{3}\right]$ & 1,344 & & & \\
\hline 8 & Modulus kehalusan [\%] & 2,923 & 2,500 & 3,500 & ASTM.C-33 \\
\hline 9 & Analisa saringan (Gradasi) & Gradasi II & & & \\
\hline
\end{tabular}

\subsection{Hasil Perancangan Komposisi Campuran}

Perancangan komposisi campuran SCC dapat dilakukan dengan beberapa cara coba-coba yaitu menggunakan cara Okamura, menggunakan acuan dari ACI atau EFNARC atau menggunakan metode SNI yang nantinya dapat dimodifikasi baik dengan cara Okamura ataupun Dreux. Pada penelitian ini cara untuk mendapatkan komposisi campuran SCC adalah dengan cara menggunakan metode SNI yang kemudian hasilnya dimodifikasi menggunakan metode Dreux. Hasil perancangan komposisi campuran yang didapatkan dapat dilihat pada Tabel $\mathbf{6}$ berikut.

Tabel 6. Hasil Perancangan Komposisi Campuran untuk $1 \mathbf{~ m}^{\mathbf{3}}$ Beton

\begin{tabular}{|c|c|c|c|c|c|c|c|c|}
\hline \multirow{2}{*}{$\begin{array}{c}\text { Trial Mix } \\
\text { Design }\end{array}$} & PCC & $\begin{array}{l}\text { Fly } \\
\text { Ash }\end{array}$ & $\begin{array}{c}\text { Agregat } \\
\text { Kasar }\end{array}$ & $\begin{array}{c}\text { Agregat } \\
\text { Halus }\end{array}$ & Air & SP & \multirow{2}{*}{$\begin{array}{c}\text { Kadar } \\
\text { Serat } \\
\text { Ijuk }\end{array}$} & \multirow{2}{*}{$\begin{array}{c}\text { Serat } \\
\text { Ijuk } \\
\text { [kg] }\end{array}$} \\
\hline & [kg] & [kg] & [kg] & [kg] & [kg] & [kg] & & \\
\hline $\mathrm{SCC}$ & 393,89 & 69,51 & 552,47 & 1.063 & 190 & 6,951 & $0,0 \%$ & 0,000 \\
\hline PFSCC $0,5 \%$ & 393,89 & 69,51 & 552,47 & 1.063 & 190 & 6,951 & $0,5 \%$ & 2,317 \\
\hline PFSCC 1\% & 393,89 & 69,51 & 552,47 & 1.063 & 190 & 6,951 & $1,0 \%$ & 4,634 \\
\hline PFSCC $1,5 \%$ & 393,89 & 69,51 & 552,47 & 1.063 & 190 & 6,951 & $1,5 \%$ & 6,951 \\
\hline PFSCC 2\% & 393,89 & 69,51 & 552,47 & 1.063 & 190 & 6,951 & $2,0 \%$ & 9,268 \\
\hline PFSCC 3\% & 393,89 & 69,51 & 552,47 & 1.063 & 190 & 6,951 & $3,0 \%$ & 13,902 \\
\hline
\end{tabular}

Penggunaan kadar superplastizicer sebanyak $6,951 \mathrm{~kg} / \mathrm{m}^{3}$ di atas didapat dari hasil trial mix di Laboratorium. Trial mix pertama dicoba kadar superplastizicer sebanyak 0,5\% terhadap berat binder, hasil pencampuran yang didapatkan seperti campuran beton normal. Trial mix kedua dicoba dengan menambahkan kadar superplastizicer sebanyak 0,5\% ke dalam campuran pertama, hasil yang didapatkan nilai s/ump flow < $485 \mathrm{~mm}$ dengan ketinggian s/ump didapatkan $15 \mathrm{~cm}$ seperti terlihat pada Gambar 5. Trial mix ketiga dicoba dengan menambahkan kadar superplastizicer sebanyak 0,5\% terhadap campuran kedua, hasil yang didapatkan nilai s/ump flow sebesar $61,5 \mathrm{~mm}$ yang nilainya masuk ke dalam batas syarat s/ump flow sebesar 485-615 mm seperti tampak pada Gambar 6. 


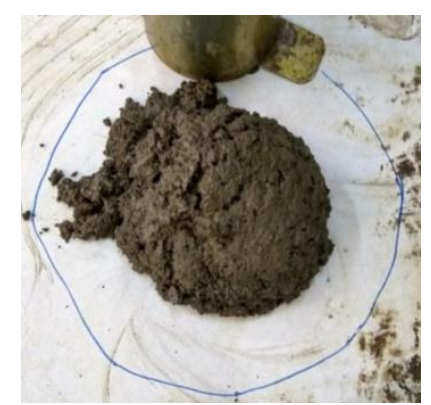

Gambar 5. Slump flow dengan kadar superplastizicer sebesar $1,0 \%$

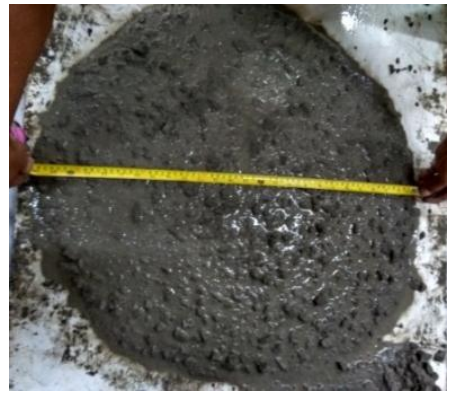

Gambar 6. Slump flow dengan kadar superplastizicer sebesar $1,5 \%$

\subsection{Hasil Pengujian Beton Segar}

Pada tahap rencana serat ijuk yang akan digunakan adalah $0 \%, 1 \%, 3 \%$ dan $5 \%$, namun setelah pengerjaan di Laboratorium penambahan kadar serat sebanyak 3\% membuat campuran sulit untuk dikerjakan karena terjadi pengendapan serat yang tampak seperti Gambar 7, sehingga pada saat proses pengerjaan campuran harus terus diaduk agar serat yang terkandung di dalamnya tersebar merata. Oleh karena itu rencana penggunaan kadar serat ijuk yang digunakan diubah menjadi $0 \% ; 0,5 \% ; 1 \% ; 1,5 \% ; 2 \%$ dan $3 \%$.

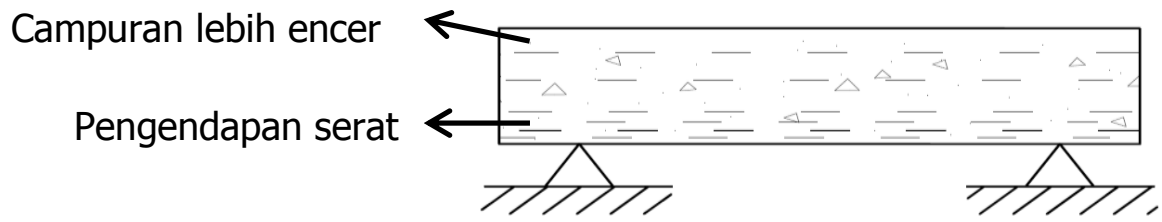

Gambar 7. Kondisi campuran dengan kadar serat ijuk sebanyak $3 \%$

Pada awal proses pengujian beton segar SCC dan PFSCC $1 \%$ hasil dari pengujian viskositas dan passing ability tidak memenuhi syarat beton SCC. Hal ini terjadi karena pada saat pengujian viskositas kondisi bagian dalam $V$-Funne/ kasar dan dibagian leher terdapat sedikit karat yang menghalangi campuran untuk mengalir. Oleh karenanya untuk mempermudah campuran keluar dari $V$-Funnel, bagian dalam permukaan $V$-Funne/ dioles pasta semen untuk memperkecil gesekan antara campuran dengan dinding permukaan. Upaya yang dilakukan tersebut berpengaruh terhadap nilai viskositas, sehingga dapat memperbaiki hasil pengujian pengujian SCC dan PFSCC $1 \%$. Berbeda dengan pengujian passing ability pengolesan pasta semen terhadap permukaan bagian dalam L-Box tidak terlalu berpengaruh, hasil yang didapatkan dari kedua percobaan hampir sama, hal ini terjadi karena ukuran maksimum agregat yang digunakan terlalu besar atau jarak antar tulangan terlalu sempit. Hasil pengujian passing ability hanya bisa diperbaiki dengan cara memperkecil ukuran agregat maksimum atau mengganti L-Box dengan jumlah 2 tulangan penghalang. Hasil pengujian beton segar dapat dilihat pada Tabel 7 berikut.

Tabel 7. Hasil Pengujian Beton Segar

\begin{tabular}{clcccccccc}
\hline No. & $\begin{array}{c}\text { Jenis Beton } \\
\text { Segar }\end{array}$ & \multicolumn{3}{c}{$\begin{array}{c}\text { Slump Flow } \\
\text { [mm] }\end{array}$} & $\begin{array}{c}\boldsymbol{T}_{\mathbf{5 0 0}} \\
\text { [detik] }\end{array}$ & $\begin{array}{c}\text { V-Funnel } \\
\text { [detik] }\end{array}$ & \multicolumn{2}{c}{ L-Box } \\
\cline { 2 - 11 } & & $\mathbf{1}$ & $\mathbf{2}$ & Rerata & Hasil & Hasil & $\boldsymbol{H}_{\mathbf{2}}$ & $\boldsymbol{H}_{\mathbf{1}}$ & $\boldsymbol{H}_{\mathbf{2}} / \boldsymbol{H}_{\mathbf{1}}$ \\
\hline 1 & SCC & 620 & 610 & 615 & 5,7 & 15 & 4 & 18 & 0,222 \\
\hline 2 & PFSCC $0,5 \%$ & 580 & 600 & 590 & 6,7 & 17 & 4 & 22,5 & 0,178 \\
\hline 3 & PFSCC 1\% & 550 & 550 & 550 & 10 & 18 & 4 & 23 & 0,174 \\
\hline 4 & PFSCC 1,5\% & 520 & 540 & 530 & 11,9 & 22 & 3 & 20 & 0,150 \\
\hline 5 & PFSCC 2\% & 440 & 480 & 460 & - & 28 & 3 & 36 & 0,083 \\
\hline 6 & PFSCC 3\% & 430 & 460 & 445 & - & 56 & 2 & 40 & 0,050 \\
\hline
\end{tabular}


Semakin banyak kadar serat ijuk yang ditambahkan ke dalam campuran membuat campuran beton segar menjadi lebih kental. Hal ini ditunjukkan dengan nilai slump flow yang semakin kecil seperti terlihat pada Gambar 8. Penurunan nilai slump flow terjadi serat di dalam campuran bekerja sebagai penghalang atau pengganggu campuran untuk mengalir. Oleh karenanya penambahan serat yang semakin banyak dapat menurunkan kemampuan beton segar untuk menyebar dan mengisi ruang seperti terlihat pada Gambar 10, semakin banyak serat, grafik yang didapatkan terhadap kemampuan flow semakin menurun sehingga waktu yang diperlukan beton segar untuk menyebar dan mengisi ruang semakin lama seperti Gambar 9 dan Gambar 11, sehingga kemampuan untuk melewati celah pada tulangan pun semakin menurun seperti Gambar 10.

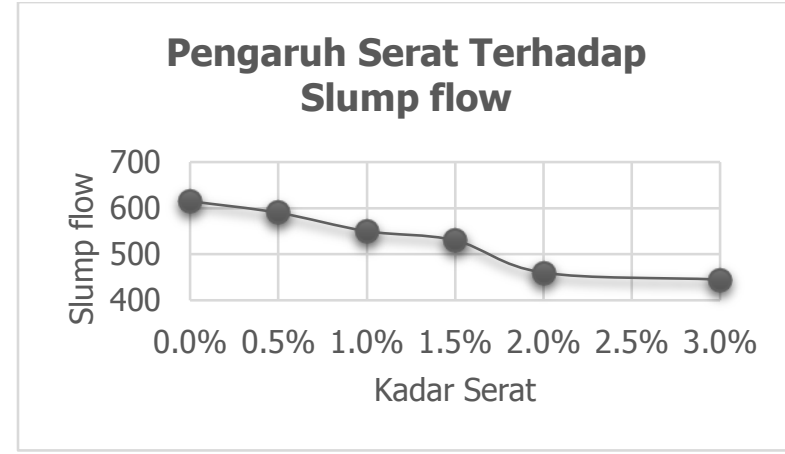

Gambar 8. Grafik pengaruh serat terhadap slump flow

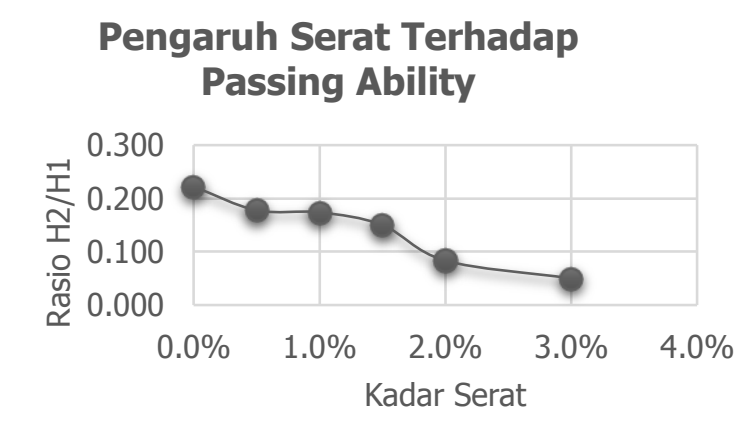

Gambar 10. Grafik pengaruh serat terhadap passing ability

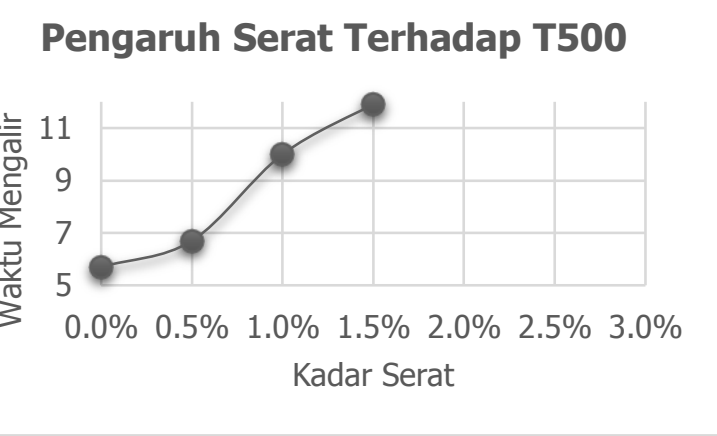

Gambar 9. Grafik pengaruh serat terhadap waktu flow

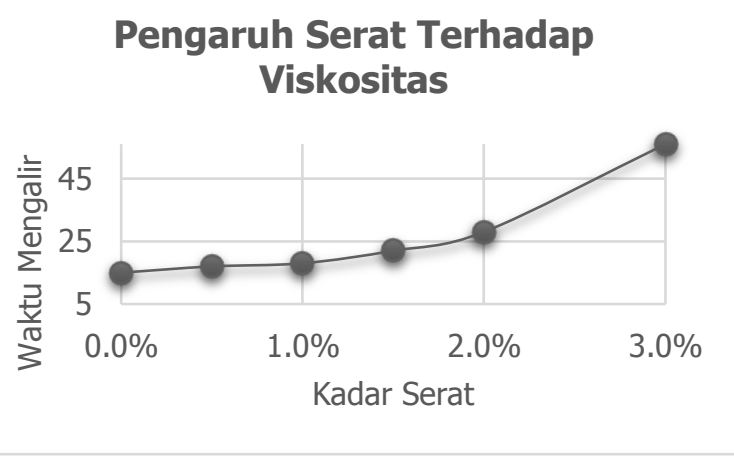

Gambar 11. Grafik pengaruh terhadap viskositas

Rerata persentase penurunan s/ump flow sebesar $6 \%$, rerata persentase peningkatan waktu uji viskositas dan $T_{500}$ sebesar $21 \%$, dan rerata persentase penurunan rasio uji passing ability sebesar $24 \%$.

\subsection{Hasil Pengujian Beton Keras}

Pengujian kuat tekan umur 14 hari dilakukan di Laboratorium Struktur Puslitbang Jalan dan Jembatan, hal ini dilakukan karena mesin UTM milik Itenas rusak, sehingga tidak bisa digunakan. Pengujian kuat tekan pada umur 28 hari dicoba dilakukan di Laboratorium Struktur dan Bahan ITENAS dengan menggunakan mesin UTM manual yang menggunakan pompa, hasil yang didapatkan dari pengujian kuat tekan rerata beton SCC umur 28 hari didapat sebesar 24 MPa lebih kecil dari kuat tekan rerata beton SCC umur 14 hari yaitu sebesar 25,4 MPa. Hal ini terjadi karena kondisi jarum pembacaan pada alat sedikit terganggu, sehingga kemungkinan hasil yang didapatkan dari mesin manual tidak akurat. Oleh karenanya pengujian 
kuat tekan dan lentur beton umur 28 hari dilakukan di Laboratorium Struktur ITB, rekapitulasi hasil pengujian kuat tekan beton disajikan pada Tabel 8 berikut.

Tabel 8. Hasil Pengujian Kuat Tekan Beton

\begin{tabular}{llcccccccc}
\hline \multirow{2}{*}{ No. } & \multirow{2}{*}{ Jenis Beton } & \multicolumn{3}{c}{ Kuat Tekan 14 Hari [MPa] } & \multicolumn{3}{c}{ Kuat Tekan 28 Hari [MPa] } \\
\cline { 3 - 9 } & & I & II & III & Rerata & I & II & III & Rerata \\
\hline 1 & SCC & 26,71 & 25,95 & 23,45 & $\mathbf{2 5 , 3 7}$ & 32,84 & 41,36 & 20,36 & $\mathbf{3 1 , 5 2}$ \\
\hline 2 & PFSCC 0,5\% & 27,75 & 25,79 & 27,98 & $\mathbf{2 7 , 1 7}$ & 33,60 & 29,14 & 30,29 & $\mathbf{3 1 , 0 1}$ \\
\hline 3 & PFSCC 1\% & 24,96 & 30,16 & 26,77 & $\mathbf{2 7 , 3 0}$ & 36,27 & 39,71 & 32,71 & $\mathbf{3 6 , 2 3}$ \\
\hline 4 & PFSCC 1,5\% & 28,92 & 28,33 & 28,23 & $\mathbf{2 8 , 4 9}$ & 27,36 & 34,49 & 35,00 & $\mathbf{3 2 , 2 8}$ \\
\hline 5 & PFSCC 2\% & 19,04 & 18,81 & 18,76 & $\mathbf{1 8 , 8 7}$ & 15,91 & 17,05 & 16,42 & $\mathbf{1 6 , 4 6}$ \\
\hline 6 & PFSCC 3\% & 18,04 & 17,50 & 17,26 & $\mathbf{1 7 , 6 0}$ & 21,76 & 18,07 & 20,24 & $\mathbf{2 0 , 0 2}$ \\
\hline
\end{tabular}

Kekuatan tekan tertinggi pada umur 14 hari terjadi pada PFSCC 1,5\% yaitu sebesar 28,495 meningkat sebesar 3,126 MPa atau menigkat sebesar $11 \%$ dari beton SCC, sedangkan pada umur 28 hari kekuatan tertinggi terjadi pada PFSCC $1 \%$ yaitu sebesar 36,23 MPa meningkat sebesar 4,709 MPa atau sebesar $13 \%$ dari beton SCC. Grafik pengaruh serat terhadap kekuatan tekan beton dapat dilihat pada Gambar 12 berikut.

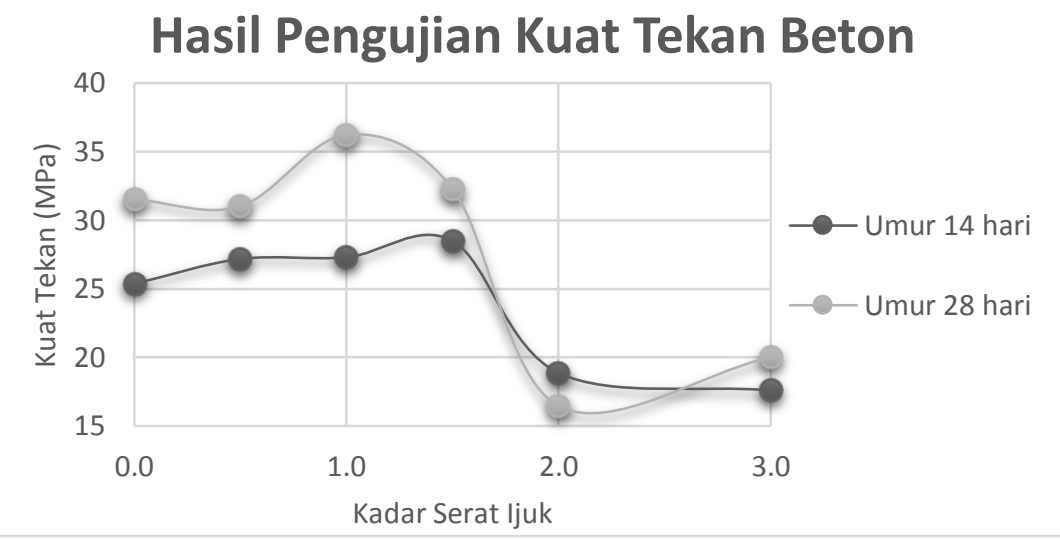

Gambar 12. Grafik pengaruh serat terhadap kekuatan tekan

Kekuatan tekan PFSCC $1 \%$ pada umur 14 hari mencapai $72 \%$ dari kekuatan tekan umur 28 hari, dan rerata kekuatan tekan beton umur 14 hari mencapai $89 \%$. Grafik pertumbuhan kekuatan tekan dapat dilihat pada Gambar 13 berikut.

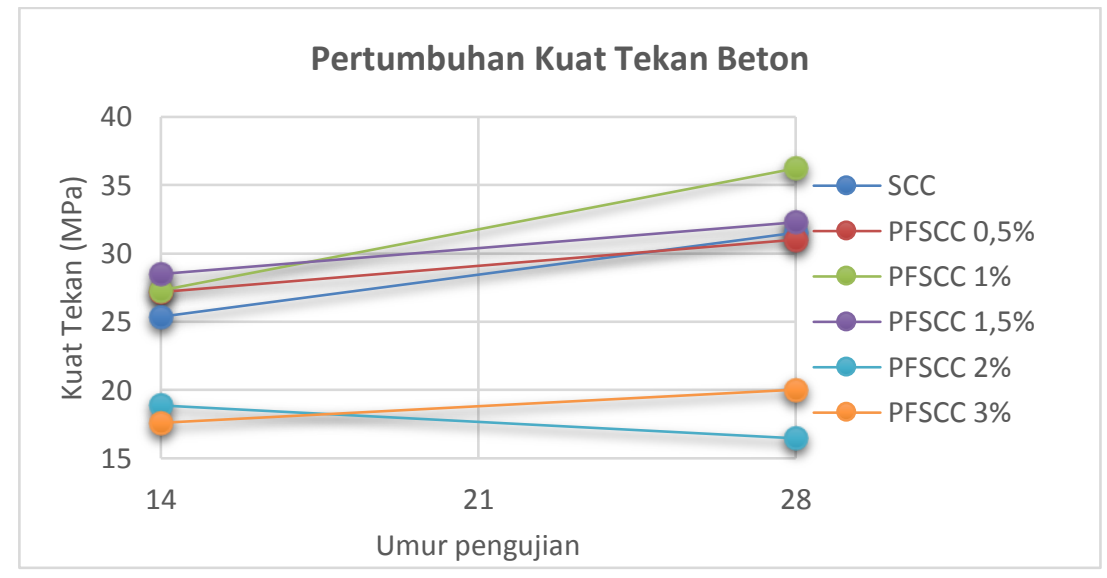

Gambar 13. Grafik pertumbuhan kuat tekan beton

Reka Racana - 63 
Rekapitulasi hasil pengujian kuat lentur di Laboratorium Struktur ITB tersaji dalam Tabel 9 berikut.

Tabel 9. Hasil Pengujian Kuat Lentur Beton

\begin{tabular}{|c|c|c|c|c|c|c|}
\hline \multirow{2}{*}{ No. } & \multirow{2}{*}{ Jenis Beton } & \multicolumn{4}{|c|}{ Kuat Lentur 28 hari [MPa] } & \multirow{2}{*}{$\frac{\boldsymbol{f}_{\boldsymbol{r}}}{\sqrt{\boldsymbol{f}_{\boldsymbol{c}}^{\prime}}}$} \\
\hline & & $\mathbf{I}$ & II & III & Rerata & \\
\hline 1 & SCC & 4,280 & 4,400 & 4,480 & 4,387 & 0,78 \\
\hline 2 & PFSCC $0,5 \%$ & 3,693 & 3,907 & 3,587 & 3,729 & 0,67 \\
\hline 3 & PFSCC $1 \%$ & 4,413 & 4,413 & 4,573 & 4,466 & 0,74 \\
\hline 4 & PFSCC $1,5 \%$ & 4,187 & 3,907 & 4,200 & 4,098 & 0,72 \\
\hline 5 & PFSCC $2 \%$ & 3,147 & 3,787 & 3,920 & 3,618 & 0,89 \\
\hline 6 & PFSCC 3\% & 3,933 & 4,133 & 3,533 & 3,866 & 0,86 \\
\hline
\end{tabular}

Menurut peraturan SNI 03-2847-2002 nilai modulus keruntuhan lentur untuk beton normal diperkirakan sebesar $f_{r}=0,7 \sqrt{f_{c}^{\prime}}$, maka apabila dipergunakan perkiraan tersebut dengan $f_{c}^{\prime}=$ 40 MPa nilai kekuatan lentur diperkirakan sebesar 4,427 MPa. Namun, karena jenis beton pada penelitian ini adalah SCC, perkiraan nilai kuat lentur $f_{r}=0,7 \sqrt{f_{c}^{\prime}}$ tidak dapat digunakan. Persamaan untuk memperkirakan nilai kekuatan lentur beton SCC belum ada, maka prediksi kekuatan lentur terhadap nilai kekuatan tekan dapat dihitung dengan cara $n=f_{r} / \sqrt{f_{c}^{\prime}}$ yang hasilnya dapat dilihat pada Tabel 9. Grafik pengaruh serat terhadap kekuatan lentur dapat dilihat pada Gambar 14. Tidak berpengaruhnya serat terhadap kekuatan lentur beton dapat diakibatkan oleh beberapa faktor seperti permukaan serat yang agak licin, dan penggunaan serat yang terlalu pendek sehingga kemungkinan pola runtuh yang terjadi tidak mengenai serat ijuk seperti tampak pada Gambar 15.

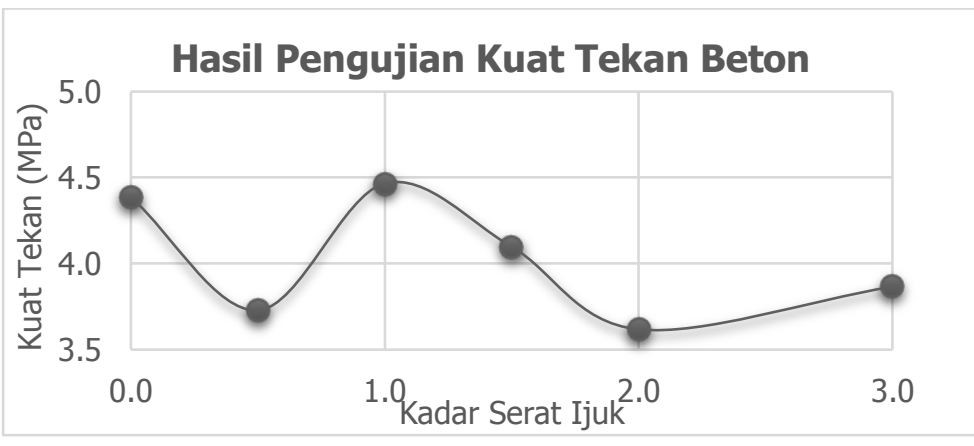

Gambar 14. Grafik pengaruh serat terhadap kekuatan lentur

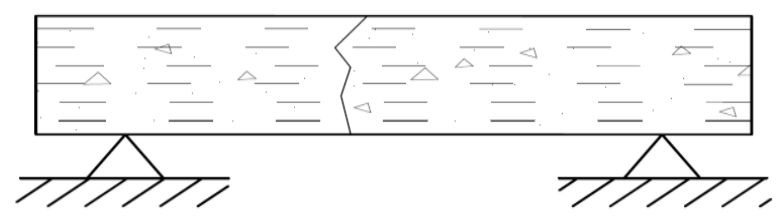

Gambar 15. Pola runtuh benda uji PFSCC

\section{KESIMPULAN}

Hasil pengujian passing ability tidak memenuhi syarat SCC karena ukuran agregat maksimum yang digunakan terlalu besar, kekuatan tekan tertinggi umur 14 hari terjadi pada beton PFSCC $1,5 \%$ yaitu sebesar $28,495 \mathrm{MPa}$, pada umur 28 hari terjadi pada PFSCC $1 \%$ sebesar 36,23 $\mathrm{MPa}$, penambahan kadar serat ijuk sebanyak $1 \%$ dapat meningkatkan kemampuan beton untuk menahan tekan sebesar $13 \%$, kekuatan lentur tertinggi terjadi pada beton PFSCC $1 \%$ 
yaitu sebesar 4,466 $\mathrm{MPa}$, penambahan kadar serat ijuk sebanyak $1 \%$ dapat meningkatkan kemampuan beton untuk menahan lentur sebesar 1,8\%, kurang berpengaruhnya penambahan serat terhadap kekuatan tekan dan lentur beton diakibatkan oleh permukaan serat yang agak licin dan serat yang digunakan terlalu pendek, penambahan kadar serat yang baik dari hasil penelitian ini didapatkan sebesar $0,5 \%-1,5 \%$, penambahan kadar serat ijuk melebihi $1,5 \%$ dapat dilakukan dengan syarat harus menambahkan kadar suprplastizicer ke dalam campuran, penambahan kadar serat ijuk melebihi 3\% dapat menyebabkan pengendapan serat didalam campuran dan biaya produksi beton PFSCC lebih tinggi dibandingkan dengan beton normal.

\section{SARAN}

Ukuran agregat maksimum disarankan diambil sebesar $10 \mathrm{~mm}$, formula yang dipakai dalam perancangan mix design ini masih perlu dikaji dan dipelajari lebih lanjut, alat dan mesin untuk pengujian perlu dilakukan perawatan untuk memperkecil penyimpangan hasil.

\section{DAFTAR RUJUKAN}

ASTM International. (2007). ASTM C150-07 Standard Specification for Portland Cement. West Conshohocken: ASTM International.

ASTM International. (2017). ASTM C618 Standard Specification for Coal Fly Ash or Calcined Natural Pozzolan for Use in Concrete. West Conshohocken: ASTM International.

Badan Standardisasi Nasional. (2002). SNI 03-6863-2002 tentang Metode Pengambilan Contoh dan Pengujian Abu Terbang atau Pozolan Alam sebagai Mineral Pencampur dalam Beton Semen Portland. Jakarta: Badan Standardisasi Nasional.

Badan Standardisasi Nasional. (2011). SNI 1974:2011 tentang Cara Uji Kuat Tekan Beton dengan Benda Uji Silinder. Jakarta: Badan Standardisasi Nasional.

Badan Standardisasi Nasional. (2011). SNI 4431:2011 tentang Cara Uji Kuat Lentur Beton Normal dengan Dua Titik Pembebanan. Jakarta: Badan Standardisasi Nasional.

Badan Standardisasi Nasional. (2016). SNI 4433:2016 tentang Spesifikasi Beton Segar Siap Pakai. Jakarta: Badan Standarisasi Nasional.

Badan Standardisasi Nasional. (2004). SNI 15-2049-2004 tentang Semen Portland. Jakarta: Badan Standardisasi Nasional.

Badan Standardisasi Nasional. (2008). SNI 1970:2008 tentang Cara Uji Berat Jenis dan Penyerapan Air Agregat Halus. Jakarta: Badan Standardisasi Nasional.

Badan Standardisasi Nasional. (2002). SNI 03-2847-2002 tentang Tata Cara Perhitungan Struktur Beton untuk Bangunan Gedung. Jakarta: Badan Standardisasi Nasional.

EFNARC. (2005). The European Guidelines for Self-Compacting Concrete Specification, Production and Use. European Project Group.

Herbudiman, B. dan Siregar, S. E. (2013, Oktober). Kajian Interval Rasio Air-Powder Beton Self Compacting Concrete Terkait Kinerja Kekuatan dan Flow. Konferensi Nasional Teknik Sipil (KoNTekS 7), (hal. M-3). Surakarta: Universitas Sebelas Maret (UNS).

Munandar, I., Savetlana, S., dan Sugiyanto. (2013, Juli). Kekuatan Tarik Serat Ijuk (Arenga Pinnata Merr). Jurnal FEMA, Juli 2013, 1(3), 52-58.

Okamura, H. dan Ouichi, M. (2003, April). Self-Compacting Concrete. Journal of Advanced Concrete Technology, April 2003, 1(1), 5-15.

Rochmah, N. (2017, September). Pengaruh Serat Ijuk Sebagai Bahan Tambah Terhadap Kuat Tarik Belah Beton. Jurnal Penelitian LPPM Untag Surabaya, September 2017, 02(01), 52-56.

Simarmata, A. C. N. (2015). Studi Pengaruh Faktor Air Semen Terhadap Kuat Tekan, Kuat Tarik, dan Kuat Lentur Beton Ringan dengan Serat Kawat. Tugas Akhir Program Studi Teknik Sipil. Universitas Atma Jaya Yogyakarta. Yogyakarta. 